\title{
Seasonal Variations of pH and Heavy Metals Content in Soil of Selected Housing Estates in Ogun State, Nigeria
}

\section{1*AMUJO, BT; ${ }^{2}$ ADEOFUN, CO; ${ }^{2}$ OGUNTOKE, O; ${ }^{3}$ BABALOLA, OA; ${ }^{2}$ TOWOLAWI, AT; ${ }^{2}$ OJEKUNLE, ZO}

\author{
${ }^{1}$ Department of Biological Science, Faculty of Natural and Applied Science, Chrisland University, Abeokuta; ${ }^{2}$ Department of \\ Environmental Management and Toxicology, Federal University of Agriculture, Abeokuta, Ogun State; ${ }^{3}$ Department of Soil Science and \\ Land Management; ${ }^{4}$ Department of Microbiology, Federal University of Agriculture, Abeokuta, Ogun State. *Corresponding author Email: \\ bamujo@chrislanduniversity.edu.ng,+234(0)703716 2284; adeofunco@funaab.edu.ng;oguntokeo@funaab.edu.ng; \\ babalolaoa@funaab.edu.ng; taofiktowolawi@yahoo.com; ojekunlezo@funaab.edu.ng
}

\begin{abstract}
There is a necessity to assess soil properties with the view to determining soil qualities relative to pollution and sustainability of ecosystem functions and plant productivity regardless of the scale. Soil samples (six points per site at 0-15 cm depth) from six selected housing estates across Ogun State were assessed for soil $\mathrm{pH}$ and heavy metals pollution in two dry and rainy seasons. The soil samples were digested using standard methods and analysed for seven selected metals: $\mathrm{Mn}, \mathrm{Fe}, \mathrm{Cu}, \mathrm{Zn}, \mathrm{Ni}, \mathrm{Pb}$ and $\mathrm{Cd}$ using AAS. The data obtained were subjected to descriptive and inferential statistics. Concentrations $(\mathrm{mg} / \mathrm{kg})$ of the analysed metals were observed to vary from the lowest in the $2^{\text {nd }}$ rainy season to the highest in $1^{\text {st }}$ dry season respectively as $\mathrm{Pb}: 3.57 \pm 0.02$ to $39.87 \pm 0.47, \mathrm{Cd}$ : $0.32 \pm 0.03$ to $2.65 \pm 1.02, \mathrm{Mg}: 11.94 \pm 0.76$ to $204.50 \pm 15.02$, Fe: $22.79 \pm 0.45$ to $303.50 \pm 16.52$, Cu: $0.95 \pm 0.21$ to $6.02 \pm 1.12$, Zn: $0.12 \pm 0.04$ to $12.75 \pm 0.68$, and $\mathrm{Ni}: 2.38 \pm 0.33$ to $33.89 \pm 0.37$. There were indications that the soil samples were comparatively less polluted in the rainy seasons.
\end{abstract}

\section{DOI: https://dx.doi.org/10.4314/jasem.v22i9.07}

Copyright: Copyright $\odot 2018$ Amujo et al. This is an open access article distributed under the Creative Commons Attribution License (CCL), which permits unrestricted use, distribution, and reproduction in any medium, provided the original work is properly cited.

Dates: Received: 08 July 2018; Revised: 28 August 2018; Accepted: 30 August 2018

Key words: soil qualities, ecosystem function, dry and rainy seasons, Nigeria

Eco-toxicologists have always relied on the knowledge of chemical and physical properties of soils to the susceptibility of soil to withstand pollution. Soils are usually regarded as the ultimate sink for heavy metals discharged to the environment and can be sensitive indicators for monitoring contaminants (Nwachukwu et al., 2010). Soil function would be described in terms of physical, chemical and biological properties as well as processes and compared with certain definable standard to determine whether soil is being improved or degraded by anthropogenic activities. Soils heavy metal accumulation trends may not be detected on time, because metal contamination may not lead to immediate concern in terms of toxicity, except in the case of hot spot pollution. However, the ubiquitous character and the increase of heavy-metal which flows through the soil system may cause serious problems for soil fertility, ground water quality and food chains. The presence of heavy metals in different foods constitute serious health hazard depending on their relative level e.g. cadmium injures the kidney and cause symptoms of chronic toxicity including impaired kidney function, poor productive capacity, hypertension and tumor while chromium and copper in particular cause nephritis, anuria and extensive lesion in kidney (Ismail et al., 2006). Excess level of heavy metals has caused the disruption of natural terrestrial ecosystems. A study on elemental levels in some selected arable agricultural soil in South West, Nigeria, concluded that sources of metals in farmlands are suspected to be from different sources such as fertilizer, vehicular emission and aerial deposition (Olatunji et al., 2013). The adverse effects possible from metal pollution are not only in the soil accumulation where their levels are toxic to plants and obliterate surface or ground water quality but also in the food chain to influence clinical health risks when consumed food grown on metal-contaminated soils. Soil pollution from heavy metals has recorded increasing attention in recent decades throughout the world. Some heavy metals like $\mathrm{Cd}$ is known to be rare in nature and required by plant and animal in minute quantity, they can be found in very low concentration. They are strongly toxic and can pose an environmental threat at high concentration. Heavy metals are markedly affected by soil redox potential and undergo both oxidation and redox depending on soil condition. 
This has important adverse effects for the availability and toxicity of many heavy metals. Contamination of the ecosystem by toxic metals during man's activities poses serious concern because heavy metals are not biodegradable and are persistent in the ecosystem. Once metals are introduced and contaminate the environment they will remain for a very long time, they do not degrade easily like carbon-based organic molecules (Nwadinigwe et al., 2014). Heavy metals are continuously introduced to soil via several pathways including industrial activities, irrigation, fertilization, atmospheric deposition and point source where metals are produced as a result of refining and refinishing products. Therefore, the problem of soil contamination by heavy metals is receiving global attention and the extent of soil pollution by heavy metals, and base metal ions some of which are soil micronutrients, is very alarming. The study thus assessed soil $\mathrm{pH}$ and heavy metals pollution in six housing estates for two dry and rainy seasons across Ogun State, Nigeria.

\section{MATERIALS AND METHODS}

Samples collection and analyses Soil samples were collected from six points at $0-15 \mathrm{~cm}$ depth per site and bulked. This was done across the six selected housing estates in Ogun State. The samples were observed to be air-dried for a week in the dry but two weeks in the wet seasons. The soil samples were sieved through 2 mm mesh (Towolawi et al., 2017) and digested using the method of Nurunnahar et al. (2012) with nitric, sulphuric and perchloric acids in ratio 5:1:2. Metals in the digested soil samples were analysed with Atomic Absorption Spectrometer (Buck Scientific, Model 210VGP, CT, USA). The soil pH was read according to the method of Bada et al. (2014).

Statistical analyses: The obtained data were subjected to descriptive (mean and standard deviation) and inferential (ANOVA and Duncan Multiple Range Test) statistics using IBM SPSS Version 22.

\section{RESULTS AND DISCUSSION}

Results of the levels of heavy metals during the $1^{\text {st }}$ dry and rainy season are represented in Tables 1 and 2 while $2^{\text {nd }}$ dry and rainy season are shown in Tables 3 and 4. Levels of the analysed metals in this study were compared with the standard limits of some countries (Table 5).

Soil $\mathrm{pH}$ and Microelements Properties in the $1^{\text {st }}$ Dry Season: From Table 1, the soil $\mathrm{pH}$ was observed to range from $4.31 \pm 0.13$ in Laderin to $6.23 \pm 0.10$ in Ilaro significantly $(\mathrm{p}<0.05)$. The soil ExcH results $(\mathrm{mg} / \mathrm{kg})$ were observed to range from $0.30 \pm 0.31$ in Ijebu-Ode to $0.60 \pm 0.27$ in Shagamu with no significant $(\mathrm{p}>0.05)$ difference, while the soil AcidAl $(\mathrm{mg} / \mathrm{kg}$ ) concentration was observed to be from 0.16 \pm 0.01 in Obada-Oko to $0.57 \pm 0.27$ in Shagamu significantly $(\mathrm{p}<0.05)$. The level of $\mathrm{Pb}$ was detected to range significantly $(\mathrm{p}<0.05)$ from $9.54 \pm 0.06 \mathrm{mg} /$ $\mathrm{kg}$ in Shagamu to $39.87 \pm 0.47 \mathrm{mg} / \mathrm{kg}$ in Obada-Oko.

The soil concentrations of $\mathrm{Cd}(\mathrm{mg} / \mathrm{kg}$ ) were determined to be lowest: $0.87 \pm 0.09$ in Arigbajo and highest: $2.65 \pm 1.02$ in Shagamu with no significant ( $p$ $>0.05)$ difference. The level of $\mathrm{Mn}(\mathrm{mg} / \mathrm{kg})$ was found to be between $50.18 \pm 3.19$ in Laderin and $204.50 \pm 15.02$ in Shagamu with high level $(\mathrm{p}<0.05)$ of significances. The concentrations of $\mathrm{Fe}(\mathrm{mg} / \mathrm{kg})$ were observed to range significantly $(\mathrm{p}<0.05)$ from $95.75 \pm 1.89$ in Shagamu to $303.50 \pm 16.52$ in IjebuOde. Concentrations of $\mathrm{Cu}$ and $\mathrm{Zn}(\mathrm{mg} / \mathrm{kg})$ were detected to be lowest: $2.53 \pm 0.57$ and $0.17 \pm 0.06$ in Shagamu and highest: $6.02 \pm 1.12$ and $12.75 \pm 0.68$ in Ijebu-Ode. There were significant $(\mathrm{p}<0.05)$ differences in the $\mathrm{Cu}$ and $\mathrm{Zn}$ soil levels. The levels of $\mathrm{Ni}(\mathrm{mg} / \mathrm{kg})$ in Ilaro soil were detected to be the least: $9.98 \pm 1.41$ and Arigbajo the highest Ni: $33.89 \pm 0.37$.

Table 1: Soil Micronutrients $(\mathrm{mg} / \mathrm{kg})$ and $\mathrm{pH}$ in the $1^{\text {st }}$ Dry Season

\begin{tabular}{|c|c|c|c|c|c|c|c|c|c|c|}
\hline \multicolumn{5}{|c|}{ Toxic Metals } & \multicolumn{3}{|c|}{ Heavy Metals } & \multirow[b]{2}{*}{$\mathrm{Ni}$} & \multirow[b]{2}{*}{ ExcH } & \multirow[b]{2}{*}{ AcidAl } \\
\hline Estates & $\mathrm{pH}$ & $\mathrm{Pb}$ & $\mathrm{Cd}$ & $\mathrm{Mn}$ & $\mathrm{Fe}$ & $\mathrm{Cu}$ & $\mathrm{Zn}$ & & & \\
\hline Shagamu & $\begin{array}{l}4.96 \pm \\
0.05^{b}\end{array}$ & $\begin{array}{r}9.54 \pm \\
0.06^{2}\end{array}$ & $\begin{array}{c}2.65 \pm \\
1.02^{2}\end{array}$ & $\begin{array}{r}204.50 \pm \\
15.02^{\mathrm{d}}\end{array}$ & $\begin{array}{c}95.75 \pm \\
1.89^{2}\end{array}$ & $\begin{array}{c}2.53 \pm \\
0.57^{2}\end{array}$ & $\begin{array}{c}0.17 \pm \\
0.06^{2}\end{array}$ & $\begin{array}{c}30.86 \pm \\
0.93^{d}\end{array}$ & $\begin{array}{c}0.60 \pm \\
0.27^{2}\end{array}$ & $\begin{array}{c}0.57 \pm \\
0.27\end{array}$ \\
\hline $\begin{array}{l}\text { Tiebu- } \\
\text { Ode }\end{array}$ & $\begin{array}{r}5.41 \pm \\
0.05^{-}\end{array}$ & $\begin{array}{c}31.75 \pm \\
1.50\end{array}$ & $\begin{array}{c}2.03 \pm \\
0.23^{2}\end{array}$ & $\begin{array}{r}96.25 \pm \\
4.52^{b}\end{array}$ & $\begin{array}{r}393.50 \\
16.52^{\circ}\end{array}$ & $\begin{array}{c}6.02 \pm \\
1.12^{e}\end{array}$ & $\begin{array}{r}12.75 \pm \\
0.68^{2}\end{array}$ & $\begin{array}{c}23.47= \\
0.63=\end{array}$ & $\begin{array}{c}0.30 \pm \\
0.31^{2}\end{array}$ & $\begin{array}{r}0.23 \pm \\
0.02^{2}\end{array}$ \\
\hline Laderin & $\begin{array}{r}4.31 \pm \\
0.13^{2}\end{array}$ & $\begin{array}{c}17.78 \pm \\
0.15^{\circ}\end{array}$ & $\begin{array}{c}1.89 \pm \\
0.30^{2}\end{array}$ & $\begin{array}{c}50.18 \pm \\
3.19^{2}\end{array}$ & $\begin{array}{r}150.25 \\
\pm 8.02^{\mathrm{b}}\end{array}$ & $\begin{array}{l}3.12 \pm \\
0.70^{-b}\end{array}$ & $\begin{array}{c}2.83 \pm \\
0.15^{d}\end{array}$ & $\begin{array}{c}21.60= \\
0.83^{b e}\end{array}$ & $\begin{array}{c}0.47 \pm \\
0.11^{2}\end{array}$ & $\begin{array}{c}0.26 \pm \\
0.01^{2}\end{array}$ \\
\hline Arigbajo & $\begin{array}{r}6.15 \pm \\
0.09=\end{array}$ & $\begin{array}{r}24.51 \pm \\
0.22^{\mathrm{a}}\end{array}$ & $\begin{array}{c}0.87 \pm \\
0.09^{2}\end{array}$ & $\begin{array}{r}140.00 \pm \\
8.76^{\circ}\end{array}$ & $\begin{array}{r}239.25 \\
\pm 9.22^{d}\end{array}$ & $\begin{array}{c}4.03 \pm \\
0.95^{b}\end{array}$ & $\begin{array}{c}1.40 \pm \\
0.07^{c}\end{array}$ & $\begin{array}{c}33.89 \pm \\
0.37\end{array}$ & $\begin{array}{c}0.52 \pm \\
0.29^{2}\end{array}$ & $\begin{array}{c}0.18 \pm \\
0.01^{2}\end{array}$ \\
\hline $\begin{array}{l}\text { Obada- } \\
\text { Oke }\end{array}$ & $\begin{array}{c}5.61 \pm \\
0.15^{d}\end{array}$ & $\begin{array}{c}39.87 \pm \\
0.47^{i}\end{array}$ & $\begin{array}{c}2.10 \pm \\
0.11^{2}\end{array}$ & $\begin{array}{c}97.75 \pm \\
4.39^{b}\end{array}$ & $\begin{array}{r}127.25 \\
\pm 8.88^{b}\end{array}$ & $\begin{array}{c}3.24 \pm \\
0.48^{2}\end{array}$ & $\begin{array}{l}0.99 \pm \\
0.08^{\mathrm{be}}\end{array}$ & $\begin{array}{c}21.38 \pm \\
1.61^{b}\end{array}$ & $\begin{array}{c}0.46 \pm \\
0.06^{2}\end{array}$ & $\begin{array}{c}0.16 \pm \\
0.01^{2}\end{array}$ \\
\hline Ilaro & $\begin{array}{r}6.23 \pm \\
0.10^{=}\end{array}$ & $\begin{array}{c}12.77 \pm \\
.57^{\mathrm{b}}\end{array}$ & $\begin{array}{c}2.61 \pm \\
0.11^{2}\end{array}$ & $\begin{array}{r}141.50 \pm \\
3.70^{\mathrm{c}}\end{array}$ & $\begin{array}{c}208.50 \pm \\
25.95^{\circ}\end{array}$ & $\begin{array}{l}3.77 \pm \\
0.02^{\mathrm{b}}\end{array}$ & $\begin{array}{l}0.49 \pm \\
0.07^{ \pm b}\end{array}$ & $\begin{array}{c}9.98 \pm \\
1.41^{2}\end{array}$ & $\begin{array}{c}0.41 \pm \\
0.25^{2}\end{array}$ & $\begin{array}{c}0.18 \pm \\
0.02^{2}\end{array}$ \\
\hline
\end{tabular}

Results in Mean $\pm S D$, same superscripts down the column are not significantly different $(p<0.05)$ 
Table 2: Soil Micronutrients $(\mathrm{mg} / \mathrm{kg})$ and $\mathrm{pH}$ in the $1^{\text {st }}$ Rainy Season

\begin{tabular}{|c|c|c|c|c|c|c|c|c|c|c|}
\hline \multicolumn{5}{|c|}{ Toxic Metals } & \multicolumn{3}{|c|}{ Heavy Metals } & \multirow[b]{2}{*}{$\mathbf{N i}$} & \multirow[b]{2}{*}{ ExcH } & \multirow[b]{2}{*}{ AcidAl } \\
\hline Estates & pH & $\mathbf{P b}$ & Cd & Mn & $\mathrm{Fe}$ & $\mathbf{C u}$ & $\mathbf{Z n}$ & & & \\
\hline Shagamu & $\begin{array}{l}7.29 \pm \\
0.07^{\mathrm{b}}\end{array}$ & $\begin{array}{l}3.71 \pm \\
0.02^{\mathrm{a}}\end{array}$ & $\begin{array}{l}1.03 \pm \\
0.40^{\mathrm{b}}\end{array}$ & $\begin{array}{l}50.58 \pm \\
3.72^{\mathrm{d}}\end{array}$ & $\begin{array}{l}23.68 \pm \\
0.47^{\mathrm{a}}\end{array}$ & $\begin{array}{l}0.98 \pm \\
0.22^{\mathrm{a}}\end{array}$ & $\begin{array}{l}0.13 \pm \\
0.03^{\mathrm{a}}\end{array}$ & $\begin{array}{l}7.63 \pm \\
0.23^{\mathrm{d}}\end{array}$ & $\begin{array}{l}0.75 \pm \\
0.33^{\mathrm{a}}\end{array}$ & $\begin{array}{l}0.70 \quad \pm \\
0.34^{\mathrm{b}}\end{array}$ \\
\hline Ijebu-Ode & $\begin{array}{l}6.33 \pm \\
0.19^{\mathrm{a}}\end{array}$ & $\begin{array}{l}6.91 \pm \\
0.06^{\mathrm{c}}\end{array}$ & $\begin{array}{l}0.73 \pm \\
0.12^{\mathrm{b}}\end{array}$ & $\begin{array}{l}12.41 \pm \\
0.79^{\mathrm{a}}\end{array}$ & $\begin{array}{l}37.16 \pm \\
1.98^{\mathrm{b}}\end{array}$ & $\begin{array}{l}1.21 \pm \\
0.27^{\mathrm{ab}}\end{array}$ & $\begin{array}{l}2.10 \pm \\
0.11^{\mathrm{d}}\end{array}$ & $\begin{array}{l}5.34 \pm \\
0.21^{\text {bc }}\end{array}$ & $\begin{array}{l}0.58 \quad \pm \\
0.14^{\mathrm{a}}\end{array}$ & $\begin{array}{l}0.32 \pm \\
0.02^{\mathrm{a}}\end{array}$ \\
\hline Laderin & $\begin{array}{l}7.96 \pm \\
0.07^{\mathrm{c}}\end{array}$ & $\begin{array}{l}12.34 \pm \\
0.58^{\mathrm{e}}\end{array}$ & $\begin{array}{l}0.79 \pm \\
0.09^{\mathrm{b}}\end{array}$ & $\begin{array}{l}23.81 \pm \\
1.12^{\mathrm{b}}\end{array}$ & $\begin{array}{l}97.33 \pm \\
4.09^{\mathrm{e}}\end{array}$ & $\begin{array}{l}2.34 \pm \\
0.44^{\mathrm{c}}\end{array}$ & $\begin{array}{l}9.46 \pm \\
0.50^{\mathrm{e}}\end{array}$ & $\begin{array}{l}5.80 \\
0.16^{\mathrm{c}}\end{array}$ & $\begin{array}{l}0.37 \pm \\
0.38^{\mathrm{a}}\end{array}$ & $\begin{array}{l}0.29 \pm \\
0.03^{\mathrm{a}}\end{array}$ \\
\hline Arigbajo & $\begin{array}{l}9.04 \pm \\
0.15^{\mathrm{e}}\end{array}$ & $\begin{array}{l}9.53 \pm \\
0.08^{\mathrm{d}}\end{array}$ & $\begin{array}{l}0.34 \pm \\
0.03^{\mathrm{a}}\end{array}$ & $\begin{array}{l}34.63 \pm \\
2.17^{\mathrm{c}}\end{array}$ & $\begin{array}{l}59.17 \pm \\
2.28^{\mathrm{d}}\end{array}$ & $\begin{array}{l}1.56 \pm \\
0.37^{\mathrm{b}}\end{array}$ & $\begin{array}{l}1.04 \pm \\
0.05^{\mathrm{c}}\end{array}$ & $\begin{array}{l}8.38 \\
0.09^{\mathrm{e}}\end{array}$ & $\begin{array}{l}0.64 \pm \\
0.36^{\mathrm{a}}\end{array}$ & $\begin{array}{l}0.22 \pm \\
0.02^{\mathrm{a}}\end{array}$ \\
\hline $\begin{array}{l}\text { Obada- } \\
\text { Oko }\end{array}$ & $\begin{array}{l}9.17 \pm \\
0.15^{\mathrm{e}}\end{array}$ & $\begin{array}{l}4.96 \pm \\
0.22^{\mathrm{b}}\end{array}$ & $\begin{array}{l}1.02 \pm \\
0.04^{\mathrm{b}}\end{array}$ & $\begin{array}{l}35.00 \pm \\
0.92^{\mathrm{c}}\end{array}$ & $\begin{array}{l}51.57 \pm \\
6.42^{\mathrm{c}}\end{array}$ & $\begin{array}{l}1.46 \pm \\
0.01^{\mathrm{ab}}\end{array}$ & $\begin{array}{l}0.36 \pm \\
0.05^{\mathrm{b}}\end{array}$ & $\begin{array}{l}2.47 \\
0.35^{\mathrm{a}}\end{array} \pm$ & $\begin{array}{l}0.51 \\
0.30^{\mathrm{a}}\end{array}$ & $\begin{array}{l}0.23 \pm \\
0.03^{\mathrm{a}}\end{array}$ \\
\hline Ilaro & $\begin{array}{l}8.25 \pm \\
0.22^{\mathrm{d}}\end{array}$ & $\begin{array}{l}15.49 \pm \\
0.18^{\mathrm{f}}\end{array}$ & $\begin{array}{l}0.81 \pm \\
0.04^{\mathrm{b}}\end{array}$ & $\begin{array}{l}24.18 \pm \\
1.09^{\mathrm{b}}\end{array}$ & $\begin{array}{l}31.47 \pm \\
2.20^{\mathrm{b}}\end{array}$ & $\begin{array}{l}1.26 \pm \\
0.19^{\mathrm{ab}}\end{array}$ & $\begin{array}{l}0.74 \pm \\
0.06^{\mathrm{bc}}\end{array}$ & $\begin{array}{l}5.29 \pm \\
0.40^{\mathrm{b}}\end{array}$ & $\begin{array}{l}0.57 \\
0.07^{\mathrm{a}}\end{array}$ & $\begin{array}{l}0.19 \pm \\
0.02^{\mathrm{a}}\end{array}$ \\
\hline
\end{tabular}

Table 3: Soil Micronutrients $\left(\mathrm{mg} / \mathrm{kg}\right.$ ) and $\mathrm{pH}$ in the $2^{\text {nd }}$ Dry Season

\begin{tabular}{lllllllllll}
\hline \multicolumn{7}{c}{ Toxic Metals } & \multicolumn{7}{c}{ Heavy Metals } \\
\hline Estates & $\mathbf{p H}$ & $\mathbf{P b}$ & $\mathbf{C d}$ & $\mathbf{M n}$ & $\mathbf{F e}$ & $\mathbf{C u}$ & $\mathbf{Z n}$ & $\mathbf{N i}$ & ExcH & AcidAl \\
\hline Shagamu & $5.71 \pm$ & $22.22 \pm$ & $0.78 \pm$ & $126.93 \pm$ & $216.92 \pm$ & $3.65 \pm$ & $1.27 \pm$ & $30.73 \pm$ & $0.48 \pm$ & $0.16 \pm$ \\
& $0.09^{\mathrm{e}}$ & $0.20^{\mathrm{d}}$ & $0.08^{\mathrm{a}}$ & $7.94^{\mathrm{c}}$ & $8.36^{\mathrm{d}}$ & $0.86^{\mathrm{b}}$ & $0.07^{\mathrm{c}}$ & $0.33^{\mathrm{e}}$ & $0.27^{\mathrm{a}}$ & $0.01^{\mathrm{a}}$ \\
Ijebu-Ode & $5.22 \pm$ & $36.14 \pm$ & $1.90 \pm$ & $88.63 \pm$ & $115.37 \pm$ & $2.94 \pm$ & $0.90 \pm$ & $19.38 \pm$ & $0.43 \pm$ & $0.15 \pm$ \\
& $0.14^{\mathrm{d}}$ & $0.43^{\mathrm{e}}$ & $0.10^{\mathrm{b}}$ & $3.98^{\mathrm{b}}$ & $8.06^{\mathrm{b}}$ & $0.43^{\mathrm{ab}}$ & $0.07^{\mathrm{bc}}$ & $1.46^{\mathrm{b}}$ & $0.05^{\mathrm{a}}$ & $0.01^{\mathrm{a}}$ \\
Laderin & $5.79 \pm$ & $11.58 \pm$ & $2.37 \pm$ & $128.29 \pm$ & $189.04 \pm$ & $3.41 \pm$ & $0.44 \pm$ & $9.05 \pm$ & $0.38 \pm$ & $0.17 \pm$ \\
& $0.09^{\mathrm{e}}$ & $0.52^{\mathrm{b}}$ & $0.10^{\mathrm{b}}$ & $3.35^{\mathrm{c}}$ & $23.53^{\mathrm{c}}$ & $0.02^{\mathrm{ab}}$ & $0.06^{\mathrm{ab}}$ & $1.27^{\mathrm{a}}$ & $0.23^{\mathrm{a}}$ & $0.02^{\mathrm{a}}$ \\
Arigbajo & $4.61 \pm$ & $8.65 \pm$ & $2.40 \pm$ & 185.41 & $86.81 \pm$ & $2.29 \pm$ & $0.15 \pm$ & $27.98 \pm$ & $0.56 \pm$ & $0.53 \pm$ \\
& $0.05^{\mathrm{b}}$ & $0.06^{\mathrm{a}}$ & $0.93^{\mathrm{b}}$ & $\pm 13.62^{\mathrm{d}}$ & $1.71^{\mathrm{a}}$ & $0.52^{\mathrm{a}}$ & $0.05^{\mathrm{a}}$ & $0.85^{\mathrm{d}}$ & $0.25^{\mathrm{a}}$ & $0.25^{\mathrm{b}}$ \\
Obada- & $5.03 \pm$ & $28.79 \pm$ & $1.84 \pm$ & $87.27 \pm$ & $356.77 \pm$ & $5.46 \pm$ & 11.56 & $21.27 \pm$ & $0.28 \pm$ & $0.22 \pm$ \\
Oko & $0.05^{\mathrm{c}}$ & $1.36^{\mathrm{f}}$ & $0.21^{\mathrm{b}}$ & $4.10^{\mathrm{b}}$ & $14.98^{\mathrm{e}}$ & $1.02^{\mathrm{c}}$ & $\pm 0.61^{\mathrm{e}}$ & $0.57^{\mathrm{c}}$ & $0.29^{\mathrm{a}}$ & $0.02^{\mathrm{a}}$ \\
Ilaro & $4.00 \pm$ & $16.12 \pm$ & $1.71 \pm$ & $45.49 \pm$ & $136.23 \pm$ & $2.83 \pm$ & $2.56 \pm$ & $19.58 \pm$ & $0.43 \pm$ & $0.24 \pm$ \\
& $0.12^{\mathrm{a}}$ & $0.14^{\mathrm{c}}$ & $0.27^{\mathrm{b}}$ & $2.90^{\mathrm{a}}$ & $7.27^{\mathrm{b}}$ & $0.63^{\mathrm{ab}}$ & $0.14^{\mathrm{d}}$ & $0.75^{\mathrm{bc}}$ & $0.10^{\mathrm{a}}$ & $0.01^{\mathrm{a}}$ \\
\hline \multicolumn{7}{c}{ Results in Mean $\pm S D$, same superscripts down the column are not significantly different $(p<0.05)$}
\end{tabular}

Table 4: Soil Micronutrients $(\mathrm{mg} / \mathrm{kg})$ and $\mathrm{pH}$ in the $2^{\text {nd }}$ Rainy Season

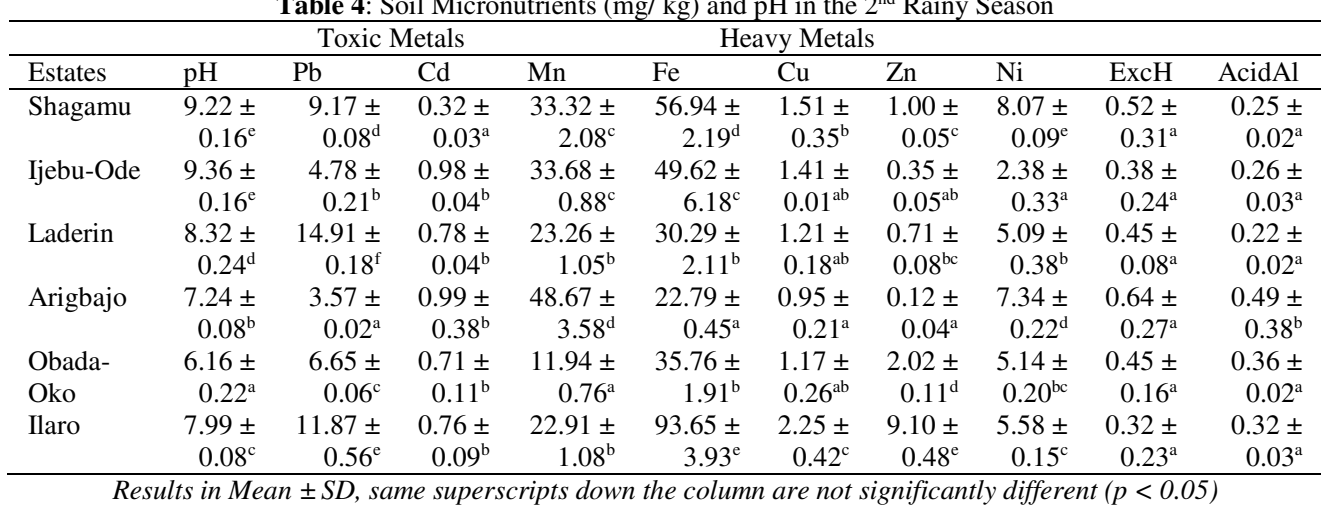

Soil pH and Microelements Properties in the $1^{\text {st }}$ Rainy Season: The results in Table 2 showed that the soil $\mathrm{pH}$ was observed to range from $6.33 \pm 0.19$ in Ijebu-Ode to $9.17 \pm 0.15$ in Arigbajo significantly $(\mathrm{p}<0.05)$. The $\mathrm{pH}$ of the $1^{\text {st }}$ dry season was observed to range from acidic to slight acidic $(4.31 \pm 0.13-6.23 \pm 0.10)$ while the $1^{\text {st }}$ rainy season ranged from slight acidic to alkaline $(6.33 \pm 0.19-9.17 \pm 0.15)$. The soil ExcH results $(\mathrm{mg} / \mathrm{kg})$ were observed to range from $0.37 \pm$ 0.38 in Laderin to $0.75 \pm 0.33$ in Shagamu with no significant ( $\mathrm{p}>0.05)$ difference. The soil AcidAl (mg/ $\mathrm{kg}$ ) concentration was observed to be from $0.19 \pm 0.02$ in Ilaro to $0.70 \pm 0.34$ in Shagamu significantly $(\mathrm{p}<$
0.05). The acidic cations (ExcH and AcidAl) were higher in the $1^{\text {st }}$ rainy season than the $1^{\text {st }}$ dry season in each estate. The level of $\mathrm{Pb}$ was detected to range significantly $(\mathrm{p}<0.05)$ from $3.71 \pm 0.02 \mathrm{mg} / \mathrm{kg}$ in Shagamu to $15.49 \pm 0.18 \mathrm{mg} / \mathrm{kg}$ in Ilaro. The soil concentrations of $\mathrm{Cd}(\mathrm{mg} / \mathrm{kg})$ were determined significantly $(\mathrm{p}<0.05)$ to be lowest: $0.34 \pm 0.03$ in Arigbajo and highest: $1.03 \pm 0.40$ in Shagamu. Concentrations of the toxic metals $(\mathrm{Pb}$ and $\mathrm{Cd})$ were observed to be lower in the $1^{\text {st }}$ rainy season than the $1^{\text {st }}$ dry season. This showed that the estate housing had not contributed to the levels of toxic metals in all the estates assessed. The level of $\mathrm{Mn}(\mathrm{mg} / \mathrm{kg})$ was found 
to be between $12.41 \pm 0.79$ in Ijebu-Ode and $50.58 \pm$ 3.72 in Shagamu with high level $(\mathrm{p}<0.05)$ of significances. The concentrations of $\mathrm{Fe}(\mathrm{mg} / \mathrm{kg})$ were observed to range significantly $(\mathrm{p}<0.05)$ from 23.68 \pm 0.47 in Shagamu to $97.33 \pm 4.09$ in Laderin. Concentrations of $\mathrm{Cu}$ and $\mathrm{Zn}(\mathrm{mg} / \mathrm{kg})$ were detected to be lowest: $0.98 \pm 0.22$ and $0.13 \pm 0.03$ in Shagamu and highest: $2.34 \pm 0.44$ and $9.46 \pm 0.50$ in Laderin. There were significant $(\mathrm{p}<0.05)$ differences in the soil concentrations of $\mathrm{Cu}$ and $\mathrm{Zn}$. The levels of $\mathrm{Ni}(\mathrm{mg} / \mathrm{kg})$ in Obada-Oko soil were detected to be the least: 2.47 \pm 0.35 and Arigbajo the highest Ni: $8.38 \pm 0.09$. It was observed that heavy metals levels were lower in the $1^{\text {st }}$ rainy season than the $1^{\text {st }}$ dry season.

Soil $\mathrm{pH}$ and Microelements Properties in the $2^{\text {nd }}$ Dry Season: It showed in Table 3 that the soil $\mathrm{pH}$ was determined to range from $4.00 \pm 0.12$ in Ilaro to 5.79 \pm 0.09 in Laderin. The soil $\mathrm{pH}$ was significantly $(\mathrm{p}<$ $0.05)$ different. The range of $\mathrm{pH}$ was observed to be more acidic $(4.00 \pm 0.12$ to $5.79 \pm 0.09)$ in the $2^{\text {nd }}$ dry season than $(4.31 \pm 0.13$ to $6.23 \pm 0.10)$ in the $1^{\text {st }}$ dry season. The soil ExcH results $(\mathrm{mg} / \mathrm{kg}$ ) were observed to range from $0.28 \pm 0.29$ in Obada-Oko to $0.56 \pm 0.25$ in Arigbajo with no significant $(\mathrm{p}>0.05)$ difference. The soil AcidAl (mg/ kg) concentration was detected to be from $0.15 \pm 0.01$ in Ijebu-Ode to $0.53 \pm 0.25$ in Arigbajo significantly $(\mathrm{p}<0.05)$. The level of $\mathrm{Pb}$ was detected to range significantly $(\mathrm{p}<0.05)$ from $8.65 \pm$ $0.06 \mathrm{mg} / \mathrm{kg}$ in Arigbajo to $36.14 \pm 0.43 \mathrm{mg} / \mathrm{kg}$ in Ijebu-Ode. The soil concentrations of $\mathrm{Cd}(\mathrm{mg} / \mathrm{kg})$ were determined to be lowest: $0.78 \pm 0.08$ in Shagamu and highest: $2.40 \pm 0.93$ in Arigbajo with significant $(\mathrm{p}<0.05)$ difference. The level of $\mathrm{Mn}(\mathrm{mg} / \mathrm{kg})$ was found to be between $45.49 \pm 2.90$ in Ilaro and 185.41 \pm 13.62 in Arigbajo with high level $(\mathrm{p}<0.05)$ of significance. The concentrations of $\mathrm{Fe}(\mathrm{mg} / \mathrm{kg})$ were observed to range significantly $(\mathrm{p}<0.05)$ from 86.81 \pm 1.71 in Arigbajo to $356.77 \pm 14.98$ in Obada-Oko. Concentrations of $\mathrm{Cu}$ and $\mathrm{Zn}(\mathrm{mg} / \mathrm{kg})$ were detected to be lowest: $2.29 \pm 0.52$ and $0.15 \pm 0.05$ in Arigbajo and highest: $5.46 \pm 1.02$ and $11.56 \pm 0.61$ in ObadaOko. There were significant $(\mathrm{p}<0.05)$ differences in the soil concentrations of $\mathrm{Cu}$ and $\mathrm{Zn}$. The levels of $\mathrm{Ni}$ $(\mathrm{mg} / \mathrm{kg})$ in Laderin soil were detected to be the least: $9.05 \pm 1.27$ and Shagamu the highest $\mathrm{Ni}: 30.73 \pm 0.33$. It was observed that though the range of $\mathrm{pH}$ was more acidic in the $2^{\text {nd }}$ dry season than in the $1^{\text {st }}$ dry season, the range of concentrations of metals (toxic and heavy) detected were lower in the $2^{\text {nd }}$ dry season than in the $1^{\text {st }}$ dry season. This implied that the more acidic the soil $\mathrm{pH}$ the less adsorbed these metals were to the soil and the metals were in turn available for plant accumulation.
Soil pH and Microelements Properties in the $2^{\text {nd }}$ Rainy Season: It could be observed in Table 4 that the soil $\mathrm{pH}$ was determined to range from $6.16 \pm 0.22$ in Obada-Oko to $9.36 \pm 0.16$ in Ijebu-Ode significantly $(\mathrm{p}<0.05)$. It was observed there was no different between the range of $\mathrm{pH}$ of the $1^{\text {st }}$ and $2^{\text {nd }}$ dry seasons: slightly acidic to alkaline $(6.16 \pm 0.22-9.36 \pm 0.16)$. The $2^{\text {nd }}$ dry season was acidic $(4.00 \pm 0.12-5.79 \pm$ 0.09 ) while the $2^{\text {nd }}$ rainy season ranged from slightly acidic to alkaline $(6.16 \pm 0.22-9.36 \pm 0.16)$. The soil ExcH results $(\mathrm{mg} / \mathrm{kg})$ were observed to range from $0.32 \pm 0.23$ in Ilaro to $0.64 \pm 0.27$ in Arigbajo with no significant ( $\mathrm{p}>0.05)$ difference. The soil AcidAl (mg/ $\mathrm{kg}$ ) concentration was observed to be from $0.22 \pm 0.02$ in Laderin to $0.49 \pm 0.38$ in Arigbajo significantly ( $p$ $<0.05)$. The soil acidic cations (ExcH and AcidAl) were lower in the $2^{\text {nd }}$ rainy season than the $1^{\text {st }}$ rainy season. The level of $\mathrm{Pb}$ was detected to range significantly $(\mathrm{p}<0.05)$ from $3.57 \pm 0.02 \mathrm{mg} / \mathrm{kg}$ in Arigbajo to $14.91 \pm 0.18 \mathrm{mg} / \mathrm{kg}$ in Laderin. The soil concentrations of $\mathrm{Cd}(\mathrm{mg} / \mathrm{kg})$ were determined significantly $(\mathrm{p}<0.05)$ to be lowest: $0.32 \pm 0.03$ in Shagamu and highest: $0.99 \pm 0.38$ in Arigbajo. Concentrations of the toxic metals $(\mathrm{Pb}$ and $\mathrm{Cd})$ were observed to be lower in the $2^{\text {nd }}$ rainy season than the $1^{\text {st }}$ rainy and $2^{\text {nd }}$ dry seasons. This showed that the housing estate anthropogenic activities had not contributed to the levels of toxic metals. The level of $\mathrm{Mn}(\mathrm{mg} / \mathrm{kg})$ was found to be between $11.94 \pm 0.76$ in Obada-Oko and $48.67 \pm 3.58$ in Arigbajo with high level $(\mathrm{p}<0.05)$ of significance. The concentrations of $\mathrm{Fe}(\mathrm{mg} / \mathrm{kg})$ were observed to range significantly $(\mathrm{p}<$ 0.05 ) from $22.79 \pm 0.45$ in Arigbajo to $93.65 \pm 3.93$ in Ilaro. Concentrations of $\mathrm{Cu}$ and $\mathrm{Zn}(\mathrm{mg} / \mathrm{kg})$ were detected to be lowest: $0.95 \pm 0.21$ and $0.12 \pm 0.04$ in Arigbajo and highest: $2.25 \pm 0.42$ and $9.10 \pm 0.48$ in Ilaro. There were significant $(\mathrm{p}<0.05)$ differences in the soil $\mathrm{Cu}$ and $\mathrm{Zn}$ concentrations. The levels of $\mathrm{Ni}$ $(\mathrm{mg} / \mathrm{kg})$ in Ijebu-Ode estate soil were detected to be the least: $2.38 \pm 0.33$ and Shagamu the highest Ni: 8.07 \pm 0.09 . The levels of heavy metals were observed lower in the $2^{\text {nd }}$ rainy season than either the $1^{\text {st }}$ rainy or $2^{\text {nd }}$ dry seasons. Comparing the metal concentrations in this study with the heavy metals thresholds in agricultural soil (Table 5), it could be inferred that the limits were not exceeded except the range of $\mathrm{Cd}$ concentrations $(0.87 \pm 0.09-2.65 \pm 1.02)$ that exceeded the Tanzania Cd standard in agricultural soil $(1.00 \mathrm{mg} /$ $\mathrm{kg}$ ) (EPMC, 2015). This implied that none of the soil samples of the assessed housing estates was polluted, with probable less health risk from microelements. Accumulation of metals in the soil and sediment is dependent on a number of external environmental factors such as $\mathrm{pH}$ for adsorption caused by the variation in grain size distribution (Inengite et al., 2010). 
Table 5: Concentrations $(\mathrm{mg} / \mathrm{kg}$ ) of heavy metals comparing with standards of some countries

\begin{tabular}{|c|c|c|c|c|c|c|c|}
\hline Country & $\mathbf{P b}$ & Cd & Mn & $\mathbf{F e}$ & $\mathrm{Cu}$ & $\mathbf{Z n}$ & $\mathbf{N i}$ \\
\hline $1^{\text {st }}$ Dry & $9.54 \pm 0.06-$ & $0.87 \pm 0.09-$ & $50.18 \pm 3.19-$ & $95.75 \pm 1.89-$ & $2.53 \pm 0.57-$ & $0.17 \pm 0.06-$ & $9.98 \pm 1.41-$ \\
\hline Season & $39.87 \pm 0.47$ & $2.65 \pm 1.02$ & $204.50 \pm 15.02$ & $303.50 \pm 16.52$ & $6.02 \pm 1.12$ & $12.75 \pm 0.68$ & $33.89 \pm 0.37$ \\
\hline $1^{\text {st }}$ Rainy & $3.71 \pm 0.02-$ & $0.34 \pm 0.03-$ & $12.41 \pm 0.79$ & $23.68 \pm 0.47-$ & $0.98 \pm 0.22-$ & $0.13 \pm 0.03-$ & $2.47 \pm 0.35-$ \\
\hline Season & $15.49 \pm 0.18$ & $1.03 \pm 0.40$ & $50.58 \pm 3.72$ & $97.33 \pm 4.09$ & $2.34 \pm 0.44$ & $9.46 \pm 0.50$ & $8.38 \pm 0.09$ \\
\hline $2^{\text {nd }}$ Dry & $8.65 \pm 0.06-$ & $0.78 \pm 0.08-$ & $45.49 \pm 2.90-$ & $86.81 \pm 1.71-$ & $2.29 \pm 0.52-$ & $0.15 \pm 0.05-$ & $9.05 \pm 1.27-$ \\
\hline Season & $36.14 \pm 0.43$ & $2.40 \pm 0.93$ & $185.41 \pm 13.62$ & $356.77 \pm 14.98$ & $5.46 \pm 1.02$ & $11.56 \pm 0.61$ & $30.73 \pm 0.33$ \\
\hline $2^{\text {nd }}$ Rainy & $3.57 \pm 0.02-$ & $0.32 \pm 0.03-$ & $11.94 \pm 0.76$ & $22.79 \pm 0.45-$ & $0.95 \pm 0.21-$ & $0.12 \pm 0.04-$ & $2.38 \pm 0.33-$ \\
\hline Season & $14.91 \pm 0.18$ & $0.99 \pm 0.38$ & $48.67 \pm 3.58$ & $93.65 \pm 3.93$ & $2.25 \pm 0.42$ & $9.10 \pm 0.48$ & $8.07 \pm 0.09$ \\
\hline Australia & 300 & 3 & & & 100 & 500 & 60 \\
\hline Canada & 200 & 3 & - & - & 150 & 500 & 100 \\
\hline China & 80 & $0.3-0.6$ & - & - & $50-200$ & $200-300$ & $40-60$ \\
\hline Germany & 1000 & 5 & - & - & 200 & 600 & 200 \\
\hline Tanzania & 200 & 1 & - & - & 200 & 150 & 100 \\
\hline Netherlands & 530 & 13 & - & - & 190 & 720 & 100 \\
\hline $\mathrm{NZ}$ & 160 & 3 & - & - & $>10^{4}$ & - & - \\
\hline UK & - & 1.8 & - & - & - & - & 230 \\
\hline USA & 200 & 0.48 & - & - & 270 & 1100 & 72 \\
\hline
\end{tabular}

Source: EPMC (2015)

The ranges of $\mathrm{pH}$ in this study corroborated the previous study, where $\mathrm{pH}$ values of soil for wet and dry seasons were observed to be 6.23 and 6.11 with average $\mathrm{pH}$ of 6.17 (slightly acidic). A pH range of $5.90-7.29$ with mean value of $6.84 \pm 0.28$ was also recorded. The slightly acidic $\mathrm{pH}$ is peculiar to Nigerian soil and sediment (Ndimele and Kumolu-Johnson, 2012). A lower range of $\mathrm{pH}(2.90-4.60)$ and (3.10 4.60) during dry and wet seasons had been previously reported. High acidity of soil had thus been attributed to a combination of possible oxidation of $\mathrm{FeS}_{2}$ in the soil to produce sulfuric acid. Solubility, toxicity and or availability of the heavy metals cations $\left(\mathrm{Cd}^{2+}, \mathrm{Cr}^{3+}\right.$, $\mathrm{Cu}^{2+}$ and $\mathrm{Zn}^{2+}$ ) to organisms decrease as soil $\mathrm{pH}$ increases (become less acidic). The effect of soil $\mathrm{pH}$ is profound on the solubility of minerals and is regarded as a useful indicator of other soil parameters. Most minerals are more soluble or available in acidic soils than in neutral or slightly alkaline soils (Ololade et al., 2010). Levels of metals found in soil are dependent on the prevailing $\mathrm{pH}$ condition of the hypolimnion water column. Low $\mathrm{pH}$ (acidic) condition affects metal speciation and may enhance metals' solubility and possible leaching into the water column. Levels of the assessed micro elements in this study were detected to be low; this indicated possible low or no health risks to corroborate Nwadinigwe et al. (2014) who reiterated that metal concentrations below the thresholds indicated low health risk effects to the domestic animals, plants and human being.

Conclusion: Soil metal contents were observed to vary and levels were higher in the dry than in the wet seasons. The soil samples were comparatively less polluted. Available water and growing of crops in all the assessed housing estates could hardly pose metal pollution health risks. Communities could be helped with environmental samples (soil, water and plant) assessment to ensure good health and well-being for all at all stages of lives (Sustainable Development Goal 3).

\section{REFERENCES}

Bada, BS; Arowolo, TA; Ozoike, PN (2014). Assessment of heavy metal content of soil and Kenaf (Hibiscus cannabinus l.) in a nutrient degraded soil amended with dairy sludge. J. Appl. Phytotechnol. Environ. Sanit. 3(4): 137 - 145.

EPMC (Environmental Protection Ministry of China), 2015. Standards of soil environmental quality of agricultural land. Huangbanhang 69: Office of Environmental Protection Ministry of China, Beijing, China.

Inengite, AK; Oforka, NC; Osuji, LC (2010). Survey of heavy metals in sediments of Kolo creek in the Niger Delta, Nigeria. Afr. J. Environ. Sci. Technol. 4 (9): 558-566.

Ismail, K; Selda, TO; Murat, B (2006). Fresemius. Environ. Bull. 15(1): 26.

Ndimele, PE; Kumolu-Johnson, CA (2012). Some aspects of the physicochemistry and heavy metal content of water, sediment and Cynothrissa mento (Regan, 1917) from Badagry creek, Lagos, Nigeria. Trends. Appl. Sci. Res. 7: 724-736.

Nurunnahar, S; Joardar, JC; Shamima, N; Rashid, MH; Imamul Huq, SM (2012). Response of broccoli to organic amendments and accumulation of heavy metals in it. Bangladeshi J. Sci. Res. 25 (1): 1-10.

Nwachukwu, MA; Feng, H; Alinnor, J (2010). Assessment of heavy metal pollution in soil and their implications within and around mechanic 
villages. Inter. J. Enviro. Sci. Technol. 7 (2): 347358.

Nwadinigwe, CA; Udo, GJ; Nwadinigwe, AO; Ubuo, EE (2014). Dry and wet seasons' dynamics in concentrations of $\mathrm{Ni}, \mathrm{V}, \mathrm{Cd}, \mathrm{Pb}, \mathrm{Mn}, \mathrm{Fe}$, Co and $\mathrm{Zn}$ in soil samples within farm lands in Ibeno coastal area, Akwa Ibom State, Niger Delta, Nigeria. Inter. J. Sci. Technol. Res. 3 (12): 96106.

Olatunji, OS; Opeolu, BO; Fatoki, OS; Ximba, BJ (2013). Heavy metals concentration levels in selected arable agricultural soils in South Western Nigeria. Inter. J. Phys. Sci. 8 (11): 421-427.
Ololade, IA; Ajayi, IR; Gbadamosi, AE; Mohammed, OZ; Sunday, AG (2010). A study on effects of soil physico-chemical properties on cocoa production in Ondo State. Modern Appl. Sci. 4 (5): 35-43.

Towolawi, AT; Arowolo, TA; Bada, BS; Badejo, AA; Taiwo, AM (2017). Phytoextraction assessment of green amaranth (Amaranthus viridis Linn.) grown on soil amended with sewage sludge. Ife $J$. Sci. 19 (1): 133-140. 